RAPHISA.

Revista de Antropología y Filosofía de lo Sagrado Review of Anthropology and Philosophy of the Sacrum ISSN: 2530-1233 Nº 4, Julio-Diciembre (2018) pp.: 35-43

\title{
THE FEAST: SENSE AND FULLNESS IN THE EXPERIENCE OF FINITE
}

\section{LAFIESTA: SENTIDOYPLENITUD ENLAEXPERIENCIA DEL FINITO.}

\author{
Mauricio Pagano ${ }^{1}$ \\ Università degli Studi del Piemonte Orientale «Amedeo Avogadro» \\ (Italia)
}

\begin{abstract}
The feast introduces an interruption in the flow of everyday life. Within the limits marked by such an interruption, a form of experience different from the ordinary takes place. The time of feast evokes and makes present the sacred time in which events that founded human society took place. In festivals, on one hand, one can grasp and represent the meaning that grounds human experience; on the other hand, a form of full life takes place. In the modern era, festivals lose their connection with the religious dimension, and such features fade away. Yet they do not disappear entirely. They are grasped in a fragmentary way, and this is enough to turn them into marks of resistance against the reduction of human experience to a purely utilitarian dimension.
\end{abstract}

Key words: FEAST; INTERRUPTION; TIME; SENSE; FULLNESS; REDUCTION.

Resumen: La fiesta introduce una interrupción en el flujo de la vida cotidiana. Dentro de los límites marcados por tal interrupción, tiene lugar una forma de experiencia diferente de la ordinaria. El momento de la fiesta evoca y hace presente el tiempo sagrado en el que tuvieron lugar los acontecimientos que fundaron la sociedad humana. En los festivales, por un lado, uno puede captar y representar el significado que fundamenta la experiencia humana; Por otro lado, se produce una forma de vida plena. En la era moderna, los festivales pierden su conexión con la dimensión religiosa, y tales características se desvanecen. Sin embargo, no desaparecen por completo. Se captan de manera fragmentaria, y esto es suficiente para convertirlos en signos de resistencia contra la reducción de la experiencia humana a una dimensión puramente utilitaria.

Palabras clave: FIESTA; INTERRUPCIÓN; TIEMPO; SENTIDO; PLENITUD; REDUCCIÓN

[1] (maurizio.pagano@uniupo.it) Estudió en la Universidad de Turín bajo la supervisión de Luigi Pareyson. Es profesor titular de la Universidad de Eastern Piedmont y Director del Doctorado en Filosofía e Historia de la Filosofía. Fue Ganador del IX Premio en Filosofía «Provincia de Varese» por el Centro de Estudios Filosóficos de Gallarate (1973). 
"A life without parties would be like an endless road without an inn"

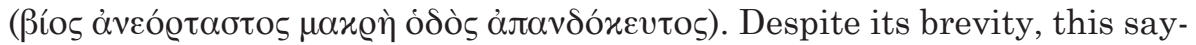
ing by Democritus (fr. 230) recalls two main features of the feast, with which we will begin our analysis ${ }^{2}$. On one hand, there is an interruption in the flow of daily life; on the other, within the limits marked by this suspension, a different form of experience is realized: a pause, which is in turn also a function of the continuation of the everyday life. The first aspect requires an intellectual operation, a boundary, which marks the temporal becoming and gives it an order, so that generally the feast is linked to the establishment of a calendar. The second aspect consists in the emergence of a different quality of life, which in the feast becomes actual. The intellectual operation is functional to the experimentation of a different experience, the time needs to be limited in order to live the feast; on the other hand, the feast has a value in itself, but is also connected to the normal time; it is a pause that gives breath, allows to better continue the everyday life and therefore has an influence on it. We can therefore speak of a qualitative interruption.

The analysis of these two aspects and their relationship can also be expressed by using another jargon, the one used by Jan Assmann in an essay in which he connects the feast to the issue of cultural memory. The human being, says the Egyptologist, is a two-dimensional being ${ }^{3}$. In this expression there is an explicit reference to the late modernity condition of the "one-dimensional man" criticized by Marcuse, but the aim of the essay is not sociological, but properly ontological. The first dimension is that of Alltag, of the everyday life, characterized by contingency, scarcity and routine. This is contrasted by a second dimension, whose features are a well-established order, fullness and a tendency to transcend the everyday life that expresses itself in reflection or in an effervescence capable of excesses. The two dimensions can be described as two forms of temporality: the first is that of everyday life, the second is the "other time", which includes the founding events of a society. In correspondence with this we can distinguish two forms of memory: the communicative memory, which ensures the functioning of daily life, and the cultural memory, which thematizes the other time and therefore has as its object all that which was founded in a distant past and establishes the unity and identity of a culture and a society.

[2] On this fragment s. N. Spineto, Dalla festa in Grecia alla festa come categoria antropologica, in S. Petrosino (ed.), La festa. Raccogliersi, riconoscersi, smarrirsi, Jaca Book, Milano 2013, pp. 35-49.

[3] J. Assmann, Der zweidimensionale Mensch: das Fest als Medium des kollektiven Gedächtnisses, in J. Assmann, Th. Sundermeier (eds.), Das Fest und das Heilige. Kontrapunkte des Alltags, Studien zum Verstehen fremder Religionen 1, Gütersloh 1991, pp. 13-30. 
For Assmann the human being is constitutively two-dimensional: the first dimension is not enough, because the world itself - or, we might say, the experience - is two-dimensional and equivocal (zweidimensional and zweideutig), and thus requires to be interpreted. The human being necessarily questions the meaning of its experience: this effort has a fundamentally collective character, and lies at the origin of culture. The meaning that from time to time human groups have developed should find expression, should be manifested: and the feast, with its rituals, is precisely the privileged place in which this sense is represented and this fullness, which illuminates the coexistence and the daily life, is made present in such a way. The feast thus assumes, according to Assmann, a central role in the cultural memory, and this is especially true for societies without writing: with the progress of society, with the use of writing and with the proliferation of cultural institutions, this centrality of the celebration tends to decrease. According to this interpretation, therefore, the feast, especially in archaic societies, is connected to the need for the relationship with "another time" and, more profoundly, with another and more fundamental dimension.

As we can see, Assmann's theory has a highly systematic profile: it assigns an important role to the feast, but places it within a general framework in which the decisive element is the necessity to elaborate meaning, conceived in turn as an entire web of beliefs and institutions that establish the identity and cohesion of a society and a culture; in this context the issue, very dear to Assmann, of cultural memory assumes a decisive importance. On this basis, the Egyptologist also gives a reason that helps to explain the fact that in recent times, especially in the modern age, the importance of the feast decreases. This last point is currently the subject of a wide discussion, and scholars often emphasize that since the eighteenth century the feast changes its character, moves away from its original religious meaning, and is rather connected to the celebration of free time. In Assmann's approach the reference to religion is not explicitly addressed and the question is then treated in a different perspective, which rather looks at the relevance that the search for the second dimension has in the different historical phases. In general I would say that Assmann's proposal provides important elements for the analysis of the feast; however, precisely because of its systematic character, it perhaps emphasizes the need to refer to the second dimension too early, and to some extent overshadows the fact that, on a phenomenological level, the sphere of everyday experience has a primary role: we live first of all in everyday life, and the feast is first experienced as a hiatus introduced in everyday life. 
Thus we could say that the feast is first of all an interruption of the Allt$a g$, the ordinary time in which everyday life goes on. The time of feast is therefore a special time, marked by activities, mostly ritual or in any case regulated, that do not take place in ordinary time: it is primarily about actions aimed to honor the gods, that is to say, sacrifices, processions, hymns and ritual dances, competitions, especially the athletic ones, but also other kinds of competitions. In several cases there are also recorded festivities that aim to the transgression of the rules that apply in normal time, or even to their inversion, as in the famous case of the carnival studied by Bakhtin: as several scholars have noted, these types of action, tending to the license or even to the excess, are permitted precisely because they take place at that precise time, expected and regulated. As Spineto reminds, the pseudo-platonic Definitions contain an entry `Eort» which defines the feast as a "sacred time determined by laws".

The time of the feast, however, is not just a special time that interrupts the ordinary one according to well-defined norms: in many important cases, in Greece but also in various other cultures, it evokes a sacred and founding time, or even makes it present. This is the time of the origins, the time of the events that, thanks to the work of the gods, heroes or ancestors, founded human society. Thanks to ritual acts this time bursts into the present time, human beings take part for a limited and determined period in the life of the gods, and this contact regenerates the present time and the human society. This phenomenon was illustrated in a particularly trenchant way by Mircea Eliade in his famous study on the myth of the eternal return, specifically dedicated to archaic cultures ${ }^{5}$. Many aspects of Eliade's theory have been questioned by subsequent research, but his analysis remains an important point of reference even today, and the idea that interests us here, namely the participation of feast time to the time of origins, remains confirmed. It is well known that Eliade opposed the circular conception of time, characteristic of the archaic cultures, to the linear one, typical of the biblical religion. In this respect, it should be recalled that even in a linear conception oriented in an eschatological sense, festival rituals connect to the foundational time, which in this case is the final one: the most evident case is that of the Eucharistic banquet, which is an anticipation of the eschatological reality of the Kingdom of God.

[4] Definitions 415 a. The essay by N. Spineto, Dalla festa in Grecia alla festa come categoria antropologica, cit., shows very well how, through a careful comment of this definition, it is possible to bring out the main characters of the festivals of ancient Greece.

[5] M. Eliade, Le mythe de l'éternel retour, Gallimard, Paris 1949; engl. trans. by Willard R. Trask, The Myth of the Eternal Return: Cosmos and History, Princeton University Press, Princeton 1971. 
In summary we can say that both in the circular conception that evokes the time of the origins, and in the eschatological conception that anticipates the final time, the time of the feast interrupts the ordinary time because it recalls and makes present the time of foundation. This foundational time is, on one hand, a time of fullness, in which human experience finds its complete fulfillment; on the other hand, it illuminates the human experience as a whole and discovers its meaning. In this perspective, the centrality of the religious dimension in the experience of the feast of archaic and ancient cultures is confirmed; I think that only by starting from here should we understand the social and political function of the feast, which certainly has an important role in strengthening the cohesion and awareness of society. This aspect, which has been underlined since the fundamental studies by Durkheim and Mauss, cannot be affirmed in a unilateral way, separating it from the religious one.

Often the experience of the feast has been brought closer to that of the game. Research on the latter topic has by now produced a vast literature, but a very prominent place is still occupied today by the classical work by Johan Huizinga, Homo Ludens, originally published in German in $1938^{6}$. Huizinga claimed the fundamental role that the game plays in the formation of culture, and proposed a definition of this activity that presents it as a free action, located outside ordinary life, placed in a delimited space and time, devoid of material interest, able to take place through an order regulated by determinate rules and to arouse social relations. He indicated the fundamental character of the game in its representative character (as Darstellung, or presentation, of a sense) and in competition. He also pointed out the close relationship that links the game to the sacred rite and the feast; the sacred action is a drama in which an event of cosmic significance is on play, it is presented (as Darstellung); the suspension of ordinary life and the limitation in time and space are also elements that link the game to the feast. According to the Dutch scholar the close relationship that links the game at the feast does not hinder to recognize that the game has a priority: "Gradually the significance of a sacred act permeates the playing. Ritual grafts itself upon it; but the primary thing is and remains play"'.

The theme of the game and its relationship with the feast also plays an important role in Wolfhart Pannenberg's anthropology, particularly in the discussion devoted to the foundations of culture. The German theologian considers Huizinga's book of great importance: Huizinga's thesis,

[6] J. Huizinga, Homo ludens, engl. trans. Homo Ludens, a study of the play element in culture, Routledge \& Kegan Paul, London 1949.

[7] Ibid., p. 18. 
which sees in the game the foundation of culture, fits with Pannenberg's perspective, which on one hand recognizes that the unity of culture cannot be founded only on myth and religion, but on the other hand rejects the "typically modern secularist prejudice", according to which culture would be only a human creation ${ }^{8}$. At the basis of culture, as well as at the basis of all human experience, there is, according to Pannenberg, an experience of sense that cannot be reduced to the meaning planned by the subject, but it is also, first and foremost, a sense that the human being encounters and receives. Huizinga's thesis on the primacy of the game should therefore be accepted, but also corrected. The game is indeed a primary experience, and the ritual game of worship is grafted onto it; but this is possible because from the beginning the game includes a component, albeit embryonic, of experience and representation of meaning. In short, the game is primary, as Huizinga maintains, but not in its purely ludic component, as the Dutch scholar would have it.

Pannenberg also accepts, and I would say with some enthusiasm, the distinction between the two fundamental aspects of the game proposed by Huizinga: for him too, Darstellung and competition are the essential components of the game experience, and it must certainly be recognized that the dimension of the competition is widely present in the game, even when we are not dealing properly with races. Nevertheless, Pannenberg's interest goes essentially to the dimension of Darstellung, that is to say the experience and the expression of meaning. In this context it is not useless to recall that Darstellung is a technical term of Hegelian thought, where it indicates the adequate presentation of truth, taken in its entirety. The special attention paid to this dimension leads Pannenberg to identify in the Darstellung of the cosmic sense the main character of the feast. The recognition of the meaning that unfolds in the feast grounds in the participants the self-understanding of their cultural and collective identity. Certainly Pannenberg specifies that this fundamental meaning must, on one hand, be grasped, and on the other hand it must also be repeated and realized, as it happens in the feast; however, in his interpretation the emphasis is above all on this rather intellectual dimension, of the grasping and the understanding of the meaning.

If we now return to the contributions that we saw before, and particularly to the suggestions of Eliade and Assmann, we must recognize that next to the aspect of the experience of meaning, the reflections on our topic often highlight the experience of fullness that is realized in the feast. The

[8] W. Pannenberg, Anthropologie in theologischer Perpektive, Vandenhoeck \& Ruprecht, Göttingen 1983, p. 311, engl. trans. by Matthew J. O'Connell, Anthropology in Theological Perspective, Bloomsbury, London 1985 , p. 322. 
two aspects are certainly connected, but they also need to be distinguished. The experience in which we grasp the fundamental sense of one's own life, as well as of the life of the community, certainly contributes to the feeling of living a fuller life, but from this point of view to be emphasized is the intellectual dimension, the need to comprehend the meaning that grounds us. The aspect of fullness, however, is primarily something to be experienced: by dancing the same dance that the gods perform on the Olympus certainly conveys a sense of harmony and a sense of sovereign cosmic order, but it is not primarily an intellectual experience: it is something that we live directly. It seems to me that this point, that is, the distinction and the connection between expression of meaning and experience of fullness, can provide useful suggestions to the reflection on the feast.

In contemporary society, or more generally in the modern era at least since the French revolution, these aspects of the feast fade away: the feast loses its essential link with the religious sphere that characterized it in ancient times, and is increasingly connected directly to the sphere of enjoyment of leisure time. The analysis of this phenomenon, well known and widely discussed, would obviously require further research; nevertheless it seems to me that from what has been said so far, some hints can at least be drawn.

Despite the many criticisms that have been raised against to the notion of meaning, I do not think that the issue can be solved by dismissing this issue. On the contrary, the question of meaning seems to grow in the contemporary experience, although it certainly struggles to find answers. What seems to be excluded, in the contemporary experience, is the demand to grasp with a glance, so to speak, the overall meaning of experience. It is true that the meaning somehow implies a form of unity of experience, but is it possible to think of a meaning, without it being governed by a dominant One? These questions have led to think that the meaning that is accessible to human beings is not encountered in the whole and does not develop into an overall conception of the real, but it can perhaps be caught in the particular, as a whole in the fragment. Developing an idea put forward by Ugo Perone ${ }^{9}$, I think that the meaning could be better glimpsed in the relationship between different relevant nuclei of finite experience: in their correlation, it is possible to grasp something that is greater than ourselves, something that does not outline a totality of meaning that we possess, but that hints at a further and deeper dimension, with which we enter into a relationship, without being able to dispose of it.

[9] Cfr. U. Perone, La secolarizzazione: un bilancio, in "Annuario Filosofico" 28 (2012), Mursia, Milano 2013, p. 128. 
Something similar applies also to the experience of fullness. First of all, fullness is by definition something that is not given in the ordinary flow of our daily time; the fullness features something that exceeds, that goes beyond our usual life. The exceedance comes before the excesses: if anything, it could be symbolized it in a more or less adequate way by the excesses described by authors such as Bakhtin and Caillois. We do not give this exceedance to ourselves, it is something we receive, as we receive a gift; and at the same time it is something that we cannot experience in loneliness, but it has to be lived and represented only in a communitarian dimension. It is already clear that fullness, like meaning, is something that is not available to us. This observation is strengthened by a second level of considerations, which directly relates to the essence of the feast as such. Les fêtes sont fragiles, feasts are fragile, wrote Nancy ${ }^{10}$ : they can end up in a bad way or even in disorders. We may add: they do not last indefinitely; they entail the return to ordinary time and its troubles. More profoundly, this reference of the feast to non-festive aspects, or even to the negative aspects of the existence, is included into the very essence of feast, inasmuch as the feast is what it is also because it is opposed to them, but cannot forget them. Thanks to a sharp phenomenological analysis of this phenomenon, Bernhard Waldenfels highlighted that in the feast, like in art, are relevant both the experience of order and harmony and the experience of chaos, both the Apollonian and the Dionysian ${ }^{11}$.

Therefore in both cases, in that of meaning as well as in that of fullness, we grasp the whole in a fragmentary way; and I would say not in a single fragment but in the plurality of fragments, in their relations, and thus also through the fractures between the fragments. In our finite condition we can grasp the whole only through fractures, and that is the reason why the whole is not available to us, and appealing to it can always be subject to questioning and criticizing. If we grasped always and only the fullness, we would be, so to speak, angels; if we never grasped it, we would be, if not animals, one-dimensional human beings. Should the difference between the everyday life dimension and the sphere of meaning and fullness disappear entirely, then it would be the total victory of the tendency to reduction, which flattens, especially in the contemporary horizon, all forms of experience to their functional dimension, to what is useful. This experience of the reduction to utility had already been described by Hegel in the Phenomenology of Spirit, as a result of the demystifying process enacted by the Enlightenment in its (partly justified) struggle against the estranged faith. But if everything is only useful for something else, in a

[10] J.-L. Nancy, Bref air de fête in "Spazio filosofico" 14 (2015), p. 212.

[11] B. Waldenfels, Feste feiern, wie sie fallen, in "Spazio Filosofico" 14, cit., p. 208 s. 
horizon of total reciprocal functionality, not only sense and fullness, but also the human meaning of life disappear.

The experience of the feast is in some way a symbol, to put it in a language that takes up that of Assmann, of non-reduction, of the dimension of richness and depth that today tends to slip away and hide, but which is in any case a constitutive and essential element of human experience. 
